See discussions, stats, and author profiles for this publication at: https://www.researchgate.net/publication/341708595

\title{
GAYA BAHASA SECARA UMUM DAN GAYA BAHASA PEMBUNGKUS PIKIRAN STILISTIKA
}

Preprint · March 2020

CITATIONS

0

1 author:

(2) Susiati Susiati

Universitas iqra buru

30 PUBLICATIONS 109 CITATIONS

SEE PROFILE

Some of the authors of this publication are also working on these related projects:

Project $\quad$ Linguist View project

Project METODE PEMBELAJARAN SOSIODRAMA View project 
GAYA BAHASA SECARA UMUM

DAN

GAYA BAHASA PEMBUNGKUS PIKIRAN

SUSIATI

PROGRAM SASTRA INDONESIA

FAKULTAS SASTRA

UNIVERSITAS IQRA BURU

2020 


\section{KATA PENGANTAR}

Materi yang berjudul gaya bahasa secara umum dan gaya bahasa pembungkus pikiran disusun untuk memenuhi tugas dari mata kuliah Stilistika. Makalah ini memberikan sebuah gambaran tentang penggunaan gaya bahasa secara umum dan gaya bahasa pembungkus pikiran, dengan makalah ini para pembaca diharapkan dapat memaksimalkan pembelajaran yng bertumpu pada pemikiran kritis dan kreatif.

Tidak ada gading yang tak retak. Penulis terbuka menerima masukan dalam rangka penyempurnaan/perbaikan. Semoga makalah ini bermanfaat untuk para pembaca.

Namlea, April 2020

Penulis 


\section{DAFTAR ISI}

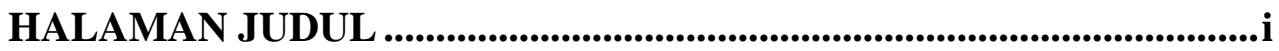

KATA PENGANTAR ........................................................................................

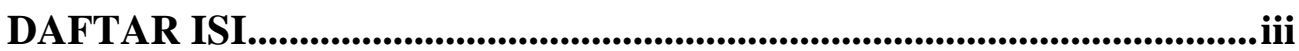

\section{BAB IPENDAHULUAN}
A. Latar Belakang
1
B. Rumusan Masalah .......................................................................... 2

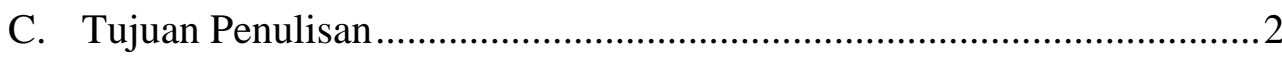

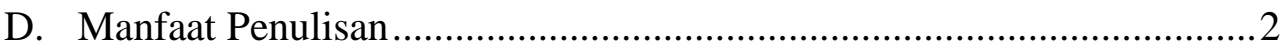

\section{BAB II PEMBAHASAN}

A. Gaya Bahasa Secara Umum ............................................................. 3

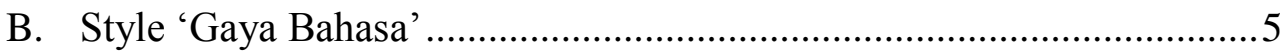

C. Hakikat Gaya Bahasa.......................................... 6

D. Gaya Bahasa Pembungkus Pikiran................................ 6

E. Ciri Khas Bahasa Sastra......................................... 7

F. Gaya Bahasa dalam Karya Sastra................................ 7

G. Fungsi Style 'Gaya Bahasa', Tujuan Stilistika,

Jenis-Jenis Gaya Bahasa........................................ 8

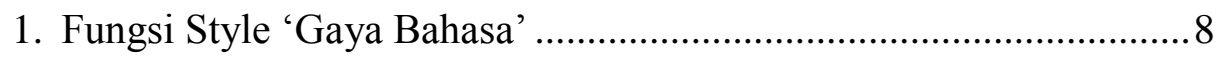

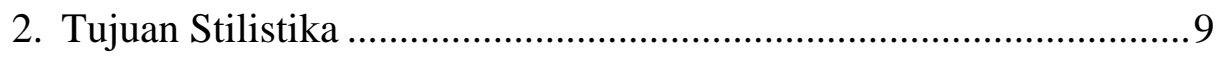

3. Jenis-Jenis Gaya Bahasa.....................................9

\section{BAB III PENUTUP}

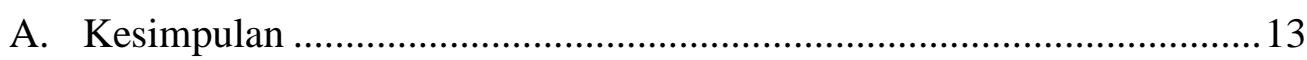

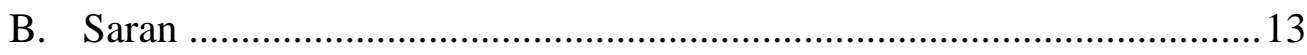

DAFTAR PUSTAKA................................................................................................... 14 


\section{BAB I \\ PENDAHULUAN}

A. Latar Belakang

Bahasa merupakan salah satu unsur terpenting dalam sebuah karya sastra. Berdasarkan yang diungkapkan Nurgiyantoro (2002: 272) bahasa dalam seni sastra ini dapat disamakan dengan cat warna. Keduanya merupakan unsur bahan, alat, dan sarana yang mengandung nilai lebih untuk dijadikan sebuah karya. Sebagai salah satu unsur terpenting tersebut, maka bahasa berperan sebagai sarana pengungkapan dan penyampaian pesan dalam sastra.

Bahasa dalam karya sastra mengandung unsur keindahan. Keindahan adalah aspek dari estetika. Pendapat tersebut sejalan dengan pendapat Zulfahnur, Gaya bahasa dan penulisan merupakan salah satu unsur yang menarik dalam sebuah bacaan. Setiap penulis mempunyai gaya yang berbeda-beda dalam menuangkan setiap ide tulisannya. Setiap tulisan yang dihasilkan nantinya mempunyai gaya penulisan yang dipengaruhi oleh penulisnya, sehingga dapat dikatakan bahwa, watak seorang penulis sangat mempengaruhi sebuah karya yang ditulisnya. Hal ini selaras dengan pendapat Pratikno (1984: 50) bahwa sifat, tabiat atau watak seseorang itu berbeda-beda.

Gaya bahasa ialah pemanfaatan kekayaan bahasa, pemakaian ragam tertentu untuk memperoleh efek-efek tertentu, keseluruhan ciri bahasa sekelompok penulis sastra dan cara khas dalam menyampaikan pikiran dan perasaan, baik secara lisan maupun tertulis.

Gaya bahasa yang digunakan oleh penulis pada hakikatnya adalah cara menggunakan bahasa yang setepat-tepatnya untuk melukiskan perasaan dan pikiran penulis yang berbeda dari corak bahasa sehari-hari dan bersifat subyektif. Untuk itulah makalah ini kami sajikan dalam hal bagaimana penggunaan gaya bahasa secara umum dan sebagai pembungkus pikiran.

B. Rumusan Masalah

1. Apa yang dimaksud dengan gaya bahasa?

2. Bagaimana gaya bahasa secara umum dan gaya bahasa pembungkus pikiran dalam karya sastra? 
3. Apa saja jenis-jenis gaya bahasa?

C. Tujuan Penulisan

1. Untuk menjelaskan tentang gaya bahasa.

2. Untuk mendiskripsikan gaya bahasa secara umum dan gaya bahasa pembungkus pikiran yang terdapat dalam karya sastra.

3. Untuk menjelaskan jenis-jenisk gaya bahasa.

D. Manfaat Penulisan

1. Memberikan pemahaman terhadap penggunaan gaya bahasa secara umum ataupun sebagai pembungkus pikiran dalam karya sastra.

2. Memberikan sumbangan pemikiran tentang gaya bahasa kepada pembaca. 


\section{BAB II}

\section{PEMBAHASAN}

\section{Peta Konsep}

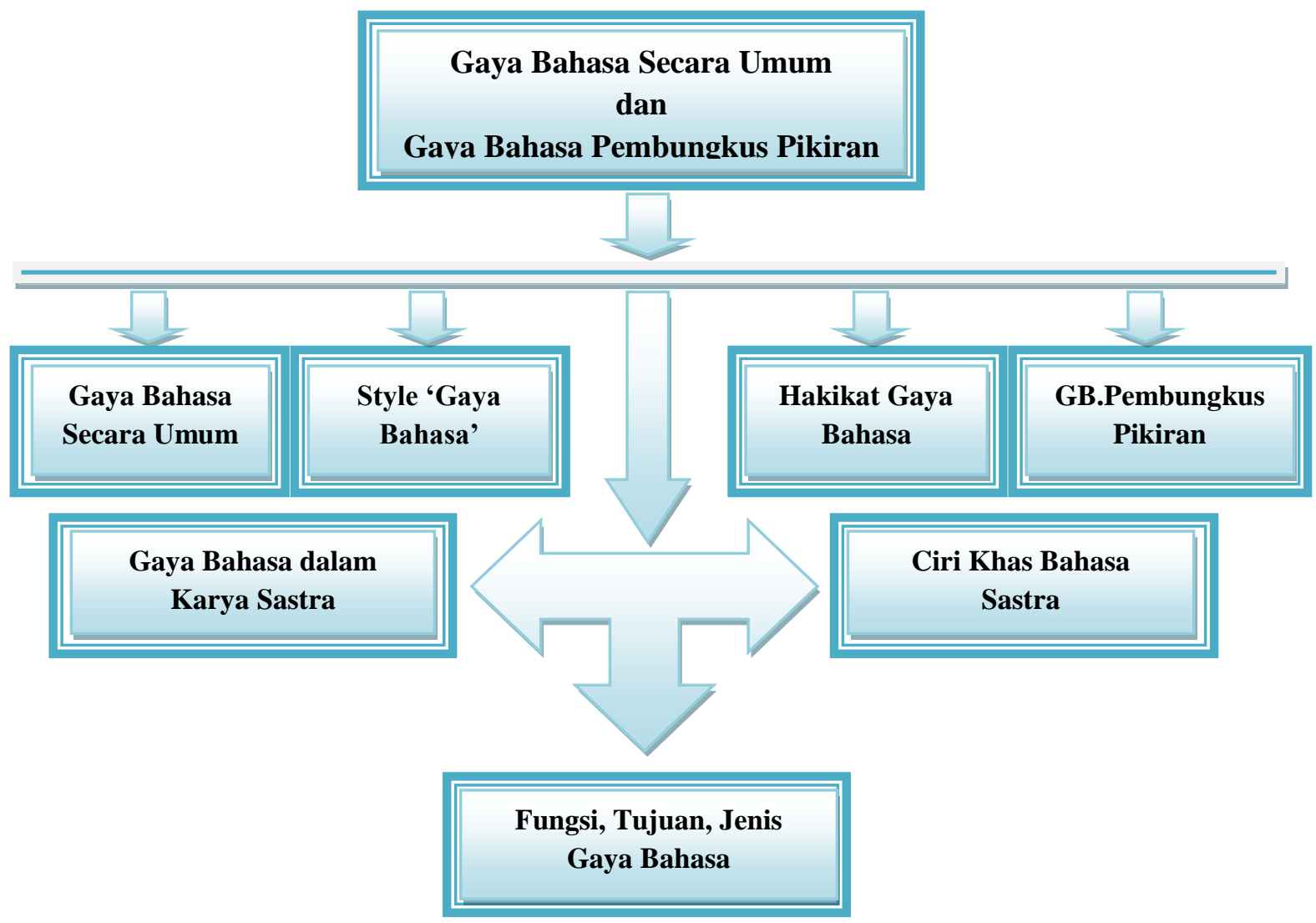

\section{A. Gaya Bahasa Secara Umum}

Gaya bahasa menurut Kamus Besar Bahasa Indonesia merupakan pemanfaatan atas kekayaan bahasa oleh seseorang dalam bertutur atau menulis; pemakaian ragam tertentu untuk memperoleh efek tertentu; keseluruhan ciri-ciri bahasa sekelompok penulis sastra; cara khas dalam menyatakan pikiran dan perasaan dalam bentuk tulis atau lisan (Depdikbud, 1995: 297).

Gaya bahasa adalah bahasa indah yang digunakan untuk meningkatkan efek dengan jalan memperkenalkan serta membandingkan suatu benda atau hal tertentu dengan benda atau hal lain yang lebih umum. Secara singkat penggunaan gaya bahasa tertentu dapat mengubah serta menimbulkan konotasi tertentu (Dale, 1971:220; Guntur Tarigan,2009 : 4). Secara singkat (Guntur Tarigan, 2009 : 4) mengemukakan 
bahwa gaya bahasa merupakan bentuk retorik, yaitu penggunaan kata-kata dalam berbicara dan menulis untuk meyakinkan atau mempengaruhi penyimak atau pembaca.

Gaya bahasa adalah cara pengucapan bahasa dalam prosa atau bagaimana seorang pengarang mengungkapkan sesuatu yang akan dikemukakan (Abrams,1981). Gaya bahasa adalah cara mengungkapkan pikiran melalui bahasa secara khas yang memperlihatkan jiwa dan kepribadian penulis atau penutur (Keraf, 1990). Dengan gaya bahasa, penutur bermaksud menjadikan paparan bahasanya menarik, kaya, padat, jelas dan lebih mampu menekankan gagasan yang ingin disampaikan, menciptakan suasana tertentu dan menampilkan efek estetis. Efek estetik tersebut menyebabkan karya sastra bernilai seni. Nilai seni karya sastra tidak semata-mata disebabkan oleh gaya bahasa saja, tapi juga oleh gaya bercerita atau penyusunan alurnya. Namun, gaya bahasalah yang sangat besar sumbangannya terhadap pencapaian nilai.

Style dapat diartikan sebagai cara khas yang dipergunakan oleh seseorang untuk mengutarakan atau mengungkapkan diri atau gaya pribadi. Pengertian style sangat luas, bisa meliputi style sekelompok pengarang, style suatu bangsa, style perseorangan, dapat juga merupakan style pada periode tertentu atau gaya penulisan tertentu (Soediro Satoto, 1995: 36). 3 ika tidak hanya merupakan studi gaya bahasa dalam kesusastraan saja, tetapi juga studi gaya dalam bahasa pada umumnya meskipun ada perhatian khusus pada bahasa kesusastraan yang paling sadar dan paling kompleks. Stilistika berguna untuk membeberkan kesan pemakaian susun kata dalam kalimat yang menyebabkan gaya kalimat, di samping ketepatan pemilihan kata, memegang peranan penting dalam ciptaan sastra.

Sudjiman berkesimpulan bahwa style dapat diterjemahkan sebagai gaya bahasa. Gaya bahasa itu sendiri mencakup diksi, struktur kalimat, majas dan citraan, pola rima, serta mantra yang digunakan seorang pengarang atau yang terdapat dalam sebuah karya sastra (bandingkan Keraf, 1981:99).

Menurut Keraf (1991: 112), gaya bahasa meliputi semua hierarki kebahasaan, yakni pilihan kata (diksi), frasa, klausa, dan kalimat, serta wacana. Senada dengan itu, Pradopo (2004: 9-14) menyatakan bahwa unsur-unsur gaya bahasa itu meliputi: (1) intonasi, (2) bunyi, (3) kata, (4) kalimat, dan (5) wacana. 
Sayuti (2000: 174) menjelaskan bahwa unsur-unsur yang membangun gaya seorang pengarang dalam karya sastranya pada dasarnya meliputi diksi, citraan, dan sintaksis.

Menurut para ahli diatas dapat disimpulkan bahwa bentuk-bentuk atau unsurunsur stilistika sebagai tanda-tanda lnguistik itu dapat berupa:

1. Fonem (phonem)

2. Leksikal atau diksi (diction)

3. Kalimat atau bentuk sintaksis

4. Wacana (discourse)

5. Bahasa figurative (figurative language atau figurative of speech)

6. Citraan (imagery)

\section{B. Style 'Gaya Bahasa'}

Kata style (bahasa Inggris) berasal dari kata Latin stilus yang berarti alat (berujung tajam) yang dipakai untuk menulis diatas lempengan lilin (Shipley, 1979: 314; Leech \& Short, 1984: 13).

Perlu kita ketahui bahwa gaya bahasa (style), sesuai dengan konteks kajiannya yakni karya sastra yang bermediumkan bahasa, style diartikan sebagai 'gaya bahasa'. Gaya bahasa adalah cara pemakaian bahasa dalam karangan, atau bagaimana seorang pengarang mengungkapkan sesuatu yang akan dikemukakan (Abrams, 1981: 190191). Menurut Leech \& Short (1984: 10), style menyaran pada cara pemakaian bahasa dalam konteks tertentu, oleh pengarang tertentu, untuk tujuan tertentu.

Chomsky menggunakan istilah deep structure (struktur batin) dan surface structure (struktur lahir), yang identik pula dengan isi dan bentuk dalam gaya bahasa (Fowler, 1997: 6). Struktur lahir adalah performansi kebahasaan dalam wujudnya yang konkret, dan itulah gaya bahasa. Adapun struktur batin merupakan gagasan yang ingin dikemukakan oleh pengarang melalui gaya bahasanya itu.

Style 'gaya bahasa' adalah cara gagasan dan perasaan dengan bahasa khas sesuai dengan kreativitas, kepribadian, dan karakter pengarang untuk mencapai efek tertentu, yakni efek estetik atau efek kepuitisan dan efek penciptaan makna.

Gaya bahasa dalam karya sastra dipakai pengarang sebagai sarana retorika dengan mengekploitasi dan memanipulasi potensi bahasa. Sarana retorika merupakan sarana kepuitisan yang berupa muslihat pikiran (Altenbernd \& Lewis, 1970: 22). 
Apabila kita bandingkan suatu karangan yang bersifat sastra dengan karangan yang biasa, maka akan nampak perbedaan bentuk pengungkapannya. Membaca karangan yang bersifat sastra akan terasa adanya suasana yang hidup, berjiwa dan estetis. Salah satu sarana untuk mengungkapkan suasana itu adalah pemakaian gaya bahasa.

Gaya bahasa adalah pemakaian kata-kata kiasan dan perbandingan yang tepat untuk melukiskan sesuatu maksud untuk membentuk plastik bahasa.

\section{Hakikat Gaya Bahasa}

Gaya bahasa atau style adalah pemanfaatan atas kekayaan bahasa oleh seseoarang dalam bertutur atau menulis; pemakaian ragam tertentu untuk memperoleh efek-efek tertentu: keseluruhan ciri-ciri bahasa sekelompok penulis sastra: cara khas dalam menyatakan pikiran dan perasaan dalam bentuk tulis atau lisan ( Hasan dalam Murtono, 2010:15). Gaya bahasa juga bermakna cara mengungkapkan pikiran melalui bahasa secara khas yang memperlihatkan jiwa dan kepribadian penulis atau pemakai bahasa (Keraf dalam Murtono, 2010:15). Gaya bahasa ini bersifat individu dan dapat juga bersifat kelompok. Gaya bahasa yang bersifat individu disebut idiolek, sedangkan yang bersifat kelompok (masyarakat) disebut dialek. Gaya bahasa memungkinkan kita dapat menilai pribadi, watak, dan watak, dan kemampuan seseorang ataupun masyarakat yang menggunakan bahasa tersebut.

\section{Gaya Bahasa Pembungkus Pikiran}

Gaya bahasa sebagai pembungkus pikiran, ide ini selalu hadir dalam benak pengarang yang selalu memanfaatkan ide-ide pemikiran mereka dalam setiap karya yang mereka hasilkan, bungkusan bahasa yang khas membuat mereka memiliki kekhasan atau keunikan tersendiri dalam setiap karyanya.

Wujud ciptaan yang dipandang sebagai hasil kegiatan bersastra pertamapetama dilihat dari sisi bahannya yaitu berupa bahasa. Sebuah karya sastra merupakan usaha merekam isi jiwa sastrawannya yaitu dengan menggunakan alat yaitu bahasa. Pemakaian bahasa pada sastra berbeda dengan pemakaian bahasa pada kegiatan yang lain, seperti pada pemakaian bahasa sehari-hari.

Karya sastra merupakan karya imajinatif bermediumkan bahasa yang fungsi estetiknya dominan. Bahasa sastra sebagai media ekspresi sastrawan dipergunakan 
untuk memperoleh nilai seni karya sastra, dalam hal ini berhubungan dengan style 'gaya bahasa' sebagai sarana sastra. Dengan demikian, plastis bahasa menjadi kebutuhan dalam bahasa sastra agar memiliki fungsi estetis yang dominan.

Bahasa sastra berhubungan dengan fungsi semiotik bahasa sastra. Bahasa merupakan sistem semiotik tingkat pertama (first order semiotics), sedangkan sastra merupakan system semiotik tingkat kedua (second order semiotics). Sebagai medium karya sastra, bahasa berkedudukan sebagai semiotik tingkat kedua dengan konvensi sastra.

\section{E. Ciri Khas Bahasa Sastra}

Sebagai sebuah media ekspresi sastrawan dalam mengemukakan gagasan melalui karyanya, bahasa sastra memiliki beberapa ciri antara lain sebagai bahasa emotif dan bersifat konotatif sebagai kebalikan bahasa nonsastra, khususnya bahasa ilmiah yang rasional dan denotatif.

Secara rinci, bahasa sastra memiliki sifat antara lain: emosional artinya bahasa sastra megandung ambiguitas yang luas yakni penuh homonim, manasuka atau kategori-kategori tak rasional; bahasa sastra diresapi peristiwa-peristiwa sejarah, kenangan dan asosisasi-asosiasi, konotatif artinya bahasa sastra mengandung banyak arti tambahan, jauh dari hanya bersifat referensial, bergaya (berjiwa) merupakan bahasa yang digunakan secara khusus untuk menimbulkan efek tertentu, khususnya efek estetis dan ketidaklangsungan ekspresi.

Puisi itu ekspresi yang tidak langsung. Meskipun teori Riffaterre ini dalam hubungannya dengan puisi, hal ini berlaku pula bagi prosa atau fiksi. Menurut Riffaterre (1978: 2) ketaklangsungan ekspresi tersebut disebabkan oleh tiga hal, yakni: penggantian arti (displacing of meaning) dilakukan dengan penggunaan metafora dan metonimia, penyimpangan arti (distorting of meaning) disebabkan oleh adanya pemakaian: ambiguitas, kontradiksi, dan nonsense, dan penciptaan arti (creating of meaning) yaitu pengorganisasian teks.

\section{F. Gaya Bahasa dalam Karya Sastra}

Gaya bahasa dapat digunakan dalam segala ragam bahasa baik ragam lisan, tulis, nonsastra, dan ragam sastra, karena gaya bahasa adalah cara menggunakan bahasa dalam konteks tertentu oleh orang tertentu untuk maksud tertentu. Akan tetapi, 
secara tradisional gaya bahasa selalu ditautkan dengan teks sastra, khususnya teks sastra tertulis. Gaya bahasa mencakup diksi atau pilihan leksikal, struktur kalimat, majas dan citraan, pola rima, matra yang digunakan seorang sastrawan atau yang terdapat dalam sebuah karya sastra.

Jorgense dan Phillips (dalam Ratna, 2009: 84) mengatakan bahwa gaya bahasa bukan sekedar sTaluran, tetapi alat yang menggerakkan sekaligus menyusun kembali dunia sosial itu sendiri. Lebih jauh menurut Simpson (dalam Ratna, 2009: 84) gaya bahasa baik bagi penulis maupun pembaca berfungsi untuk mengeksplorasi kemampuan bahasa khususnya bahasa yang digunakan. Stilistika dengan demikian memperkaya cara berpikir, cara pemahaman, dan cara perolehan terhadap substansi kultural pada umumnya.

Melalui gaya bahasa pembaca dapat menilai kepribadian dan kemampuan pengarang, semakin baik gaya bahasa yang digunakan, semakin baik pula penilaian terhadapnya. Sering dikatakan bahwa bahasa adalah pengarang yang terekam dalam karya yang dihaslkannya. Oleh sebab itu setiap pengarang mempunyai gayanya masing-masing.

\section{G. Fungsi Style 'Gaya Bahasa', Tujuan Stilistika, Jenis Gaya Bahasa}

\section{Fungsi Style 'Gaya Bahasa'}

Gaya bahasa berfungsi sebagai alat untuk meyakinkan atau mempengaruhi pembaca atau pendengar. Gaya bahasa juga berkaitan dengan situasi dan suasana pengarang. Dengan demikian, dapat dikemukakan bahwa fungsi gaya bahasa dalam karya sastra sebagai alat untuk:

a. Meninggikan selera, artinya dapat meningkatkan minat pembaca/ pendengar untuk mengikuti apa yang disampaikan pengarang/ pembicara.

b. Mempengaruhi atau meyakinkan pembaca atau pendengar, artinya dapat membuat pembaca semakin yakin dan mantap terhadap apa yang disampaikan pengarang/ pembicara.

c. Menciptakan keadaan perasaan hati tertentu, artinya dapat membawa pembaca hanyut dalam suasana hati tertentu, seperti kesan baik atau buruk, perasaan senagn atau tidak senang, benci, dan sebagainya setelah menangkap apa yang dikemukakan pengarang. 
d. Memperkuat efek terhadap gagasan, yakni dapat membuat pembaca terkesan oleh gagasan yang disampaikan pengarangalam karyanya.

\section{Tujuan Stilistika}

Dalam kedudukannya sebagai teori dan pendekatan penelitian karya sastra yang berorientasi linguistik (dengan parameter linguistik), stilistika mempunyai tujuan sebagai berikut.

Pertama, stilistika untuk menghubungkan perhatian kritikus sastra dalam apresiasi estetik dengan perhatian linguis dalam deskripsi linguistik.

Kedua, stilistika untuk menelaah bagaimana unsur-unsur bahasa ditempatkan dalam menghasilkan pesan-pesan aktual lewat pola-pola yang digunakan dalam sebuah karya sastra.

Ketiga, stilistika untuk menghubungkan intuisi-intuisi tentang makna-makna dengan pola-pola bahasa dalam teks (sastra) yang dianalisis.

Keempat, stilistika untuk menuntun pemahaman yang lebih baik terhadap makna yang dikemukakan pengarang dalam karyanya dan memberikan apresiasi yang lebih terhadap kemampuan bersastra pengarangnya.

Kelima, stilistika untuk menemukan prinsip-prinsip artistik yang mendasari pemilihan bahasa seseorang pengarang. Sebab, setiap penulis memiliki kualitas individual masing-masing.

Keenam, kajian stilistika akan menemukan kiat pengarang dalam memanfaatkan kemungkinan yang tersedia dalam bahasa sabagai sarana pengungkapan makna dan efek estetik bahasa.

\section{Jenis Gaya Bahasa}

Jenis-jenis gaya bahasa:

\begin{tabular}{|l|l|ll|}
\hline No & $\begin{array}{l}\text { Jenis gaya } \\
\text { bahasa }\end{array}$ & \multicolumn{1}{c|}{ Bagian-bagian dan Pengertiannya } \\
\hline 1 & $\begin{array}{l}\text { Gaya bahasa } \\
\text { berdasarkan } \\
\text { pilihan kata }\end{array}$ & $\begin{array}{l}\text { a. } \\
\text { b. Gaya bahasa resmi } \\
\text { c. Gaya bahasa tak resmi }\end{array}$ \\
\hline
\end{tabular}




\begin{tabular}{|c|c|c|}
\hline 2 & $\begin{array}{l}\text { Gaya bahasa } \\
\text { berdasarkan } \\
\text { nada }\end{array}$ & $\begin{array}{l}\text { a. Gaya sederhana } \\
\text { b. Gaya mulia dan bertenaga } \\
\text { c. Gaya menengah }\end{array}$ \\
\hline 3 & $\begin{array}{l}\text { Gaya bahasa } \\
\text { berdarkan } \\
\text { struktur } \\
\text { kalimat }\end{array}$ & $\begin{array}{l}\text { a. Klimaks: gaya bahasa penegasan yang menyatakan beberapa hal } \\
\text { yang berturut-turut makin lama makin memuncak. } \\
\text { b. Antiklimaks: gaya bahasa penegasan yang menyatakan beberapa hal } \\
\text { yang berturut-turut makin lama makin melemah tingkatannya. } \\
\text { c. Paralelisme: gaya bahasa penegasan yang dipakai dalam puisi } \\
\text { dengan mengulang kata-kata. Jenisnya: anaphora dan epipora. } \\
\text { d. Antithesis: gaya bahasa pertentangan dengan mempergunakan kata- } \\
\text { kata yang berlawanan artinya. } \\
\text { e. Repetisi: gaya bahasa penegasan dengan mengulang sepatah kata } \\
\text { berkali-kali dalam kalimat. }\end{array}$ \\
\hline 4 & $\begin{array}{l}\text { Gaya bahasa } \\
\text { berdasarkan } \\
\text { langsung } \\
\text { tidaknya } \\
\text { makna }\end{array}$ & $\begin{array}{l}\text { a. Gaya bahasa retorika: } \\
\text { 1. Aliterasi: gaya bahasa yang berwujud perulangan konsonan yang } \\
\text { sama. } \\
\text { 2. Asonansi: gaya bahasa berupa perulangan bunyi vocal. } \\
\text { 3. Anastrof: gaya bahasa berupa pembalikan susunan kalimat dari } \\
\text { pola yang lazim, biasanya dari subjek-predikat jadi predikat-subjek } \\
\text { 4. Apofasis/preterisio: gaya bahasa yang dipakai oleh pengarang } \\
\text { untuk menyampaikan sesuatu yang megandung unsur kontradiksi, } \\
\text { kelihatannya menolak tapi sebenarnya menerima, kelihatannya } \\
\text { memuji tapi sebenarnya mngejek, nampaknya membenarkan tapi } \\
\text { sebenarnya menyalahkan, kelihatannya merahasiakan tapi } \\
\text { sebenarnya membeberkan. } \\
\text { Apostrof: gaya bahsa berupa pengalihan pembicaraan kepada } \\
\text { benda atau sesuatu yang tidak bisa berbicara kepada kita terutama } \\
\text { kepada tokoh yang tidak hadir atau sudah tiada, dengan tujuan lebih } \\
\text { menarik atau memberi nuansa lain. } \\
\text { Asidenton: Pengungkapan suatu kalimat atau wacana tanpa kata } \\
\text { penghubung. } \\
\text { Polisindenton: Pengungkapan suatu kalimat atau wacana, } \\
\text { dihubungkan dengan kata penghubung. } \\
\text { Kiasmus: gaya bahasa yang terdiri dari dua klausa yang } \\
\text { berimabang namun dipertentangkan satu sama lain. } \\
\text { 9. Elipsis: Penghilangan satu atau beberapa unsur kalimat, yang } \\
\text { dalam susunan normal unsur tersebut seharusnya ada. } \\
\text { 10. Eufemisme: Pengungkapan kata-kata yang dipandang tabu atau } \\
\text { dirasa kasar dengan kata-kata lain yang lebih pantas atau dianggap } \\
\text { halus. } \\
\text { 11. Litotes: Litotes yaitu gaya bahasa yang menyatakan sesuatu dengan } \\
\text { cara-cara yang berlawanan dengan kenyataan, dengan cara } \\
\text { mengecilkan ataupun menguranginya. } \\
\text { 12. Hysteron proteron: gaya bahasa berupa penyusunan kalimat yang } \\
\text { mengandung pembalikan dari logika yang wajar. } \\
\text { 13. Pleonasme: Pleonasme yaitu gaya bahasa yang menggunakan kata- } \\
\text { kata atau sepatah kata secara berlebihan dengan maksud untuk } \\
\text { menegaskan arti dari suatu kata. } \\
\text { 14. Tautology: gaya bahasa yang mengulang beberapa kali sepatah } \\
\text { kata didalam suatu kalimat. } \\
\text { 15. Prifrase: gaya bahasa perbandingan dengan mengganti sebuah kata }\end{array}$ \\
\hline
\end{tabular}




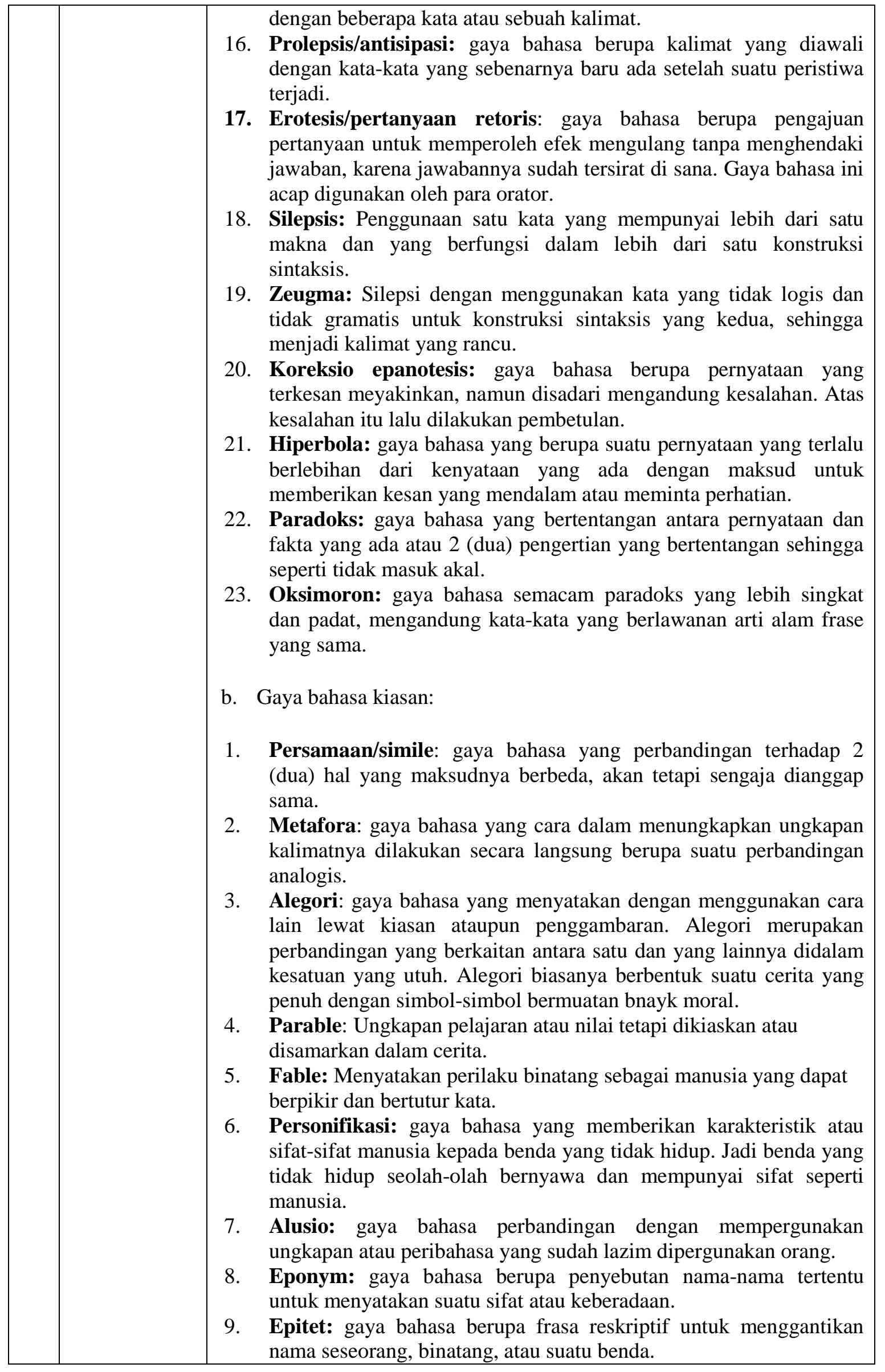




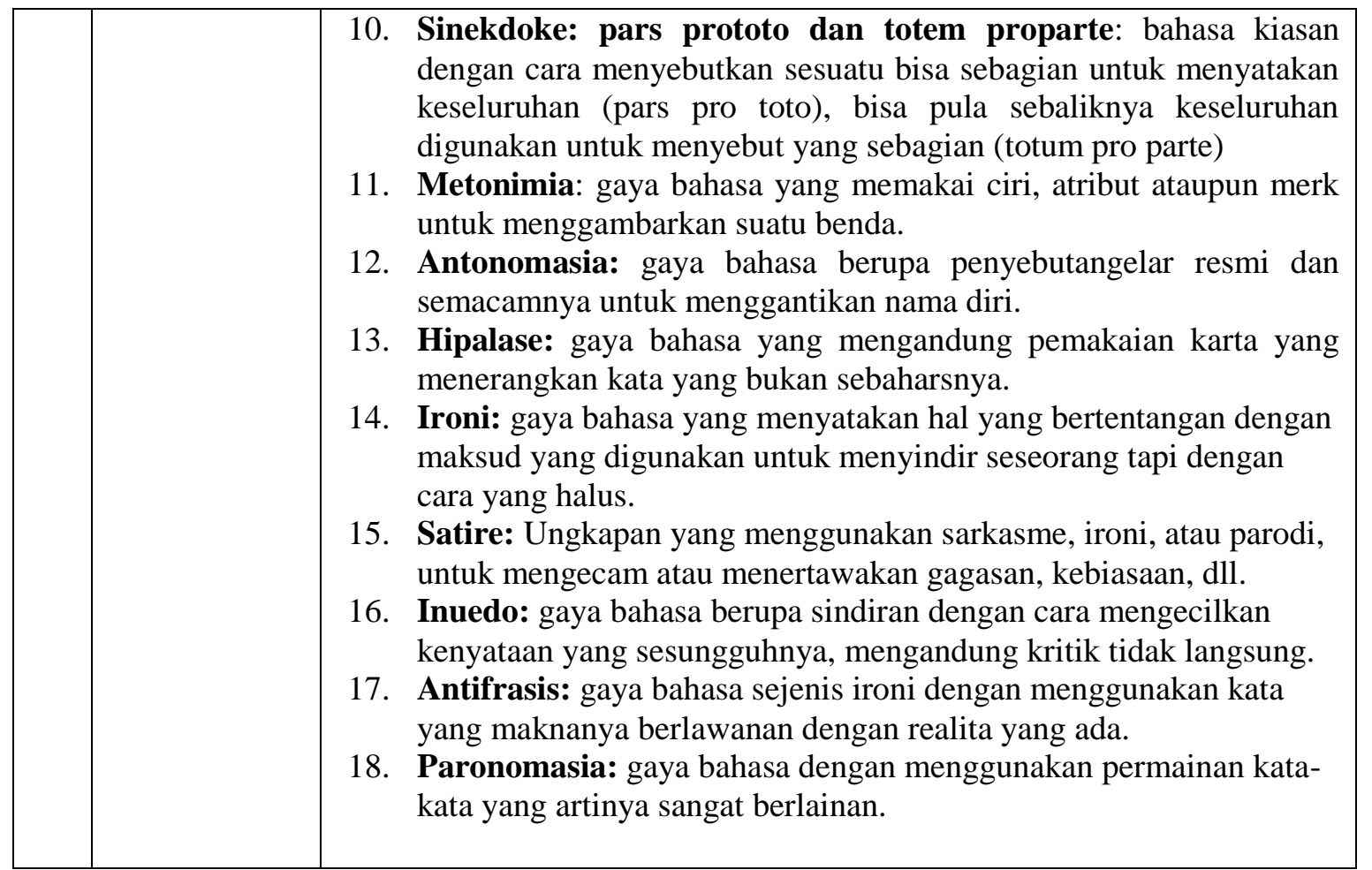

Jenis-jenis gaya bahasa pada tabel di atas menunjukkan betapa beragamnya pembungkus ide-ide dalam setiap mengungkapkan pikiran-pikiran kita. Dalam mengungkapkan setiap pemikiran tentu kita membutuhkan bahasa yang dapat dengan mudah dimengerti oleh orang lain, dan juga dalam dunia sastra alangkah indahnya bahasa yang kita gunakan dengan alat yang unik yaitu majas. 


\section{BAB III}

\section{PENUTUP}

\section{A. KESIMPULAN}

1. Gaya bahasa ialah pemanfaatan kekayaan bahasa, pemakaian ragam tertentu untuk memperoleh efek-efek tertentu, keseluruhan ciri bahasa sekelompok penulis sastra dan cara khas dalam menyampaikan pikiran dan perasaan, baik secara lisan maupun tertulis.

2. Gaya bahasa yang digunakan oleh penulis pada hakikatnya adalah cara menggunakan bahasa yang setepat-tepatnya untuk melukiskan perasaan dan pikiran penulis yang berbeda dari corak bahasa sehari-hari dan bersifat subyektif. Majas dibagi menjadi 4 kelompok yaitu gaya bahasa perbandingan, gaya bahasa sindiran, gaya bahasa penegasan dan gaya bahasa pertentangan.

3. Sudjiman berkesimpulan bahwa style dapat diterjemahkan sebagai gaya bahasa. Gaya bahasa itu sendiri mencakup diksi, struktur kalimat, majas dan citraan, pola rima, serta mantra yang digunakan seorang pengarang atau yang terdapat dalam sebuah karya sastra (bandingkan Keraf, 1981:99).

4. Menurut Keraf (1991: 112), gaya bahasa meliputi semua hierarki kebahasaan, yakni pilihan kata (diksi), frasa, klausa, dan kalimat, serta wacana. Senada dengan itu, Pradopo (2004: 9-14) menyatakan bahwa unsur-unsur gaya bahasa itu meliputi: (1) intonasi, (2) bunyi, (3) kata, (4) kalimat, dan (5) wacana.

\section{B. SARAN}

Gaya bahasa dipakai pengarang hendak memberi bentuk terhadap apa yang ingin disampaikan. Dengan gaya bahasa tertentu pula seorang pengarang dapat mengekalkan pengalaman rohaninya dan penglihatan batinnya, serta dengan itu pula ia menyentuh hati pembacanya. Karena gaya bahasa itu berasal dari dalam batin seorang pengarang maka gaya bahasa yang digunakan oleh seorang pengarang dalam karyanya secara tidak langsung menggambarkan sikap atau karakteristik pengarang tersebut. 


\section{DAFTAR PUSTAKA}

Agepe. 2008. Majas. Tersedia di http://goesprih.blogspot.com//. Diunduh pada tanggal 1 Maret 2012.

Departemen Pendidikan dan Kebudayaan. 1995. Kamus Besar Bahasa Indonesia. Jakarta: Depdikbud.

Djamudi, N. L., Nurlaela, M., Nazar, A., Nuryadin, C., Musywirah, I., \& Sari, H. (2019, October). Alternative social environment policy through educational values in Kafi'a's customary speech to the kaledupa community of Wakatobi Island, Indonesia. In IOP Conference Series: Earth and Environmental Science (Vol. 343, No. 1, p. 012118). IOP Publishing.

Imron, Ali. 2009 . Stilistika, Teori, Metode, dan Aplikasi Pengkajian Estetika Bahasa. Solo: Cakra Books.

Karsono. 2011. Ragam Gaya Bahasa. Tersedia di http://karsonojawul.blog.uns.ac.id//. Diunduh pada tanggal 1 Maret 2012.

Keraf, Gorys.2007. Diksi dan Gaya Bahasa. Jakarta : PT. Gramedia Pustaka Utama

Murtono. 2010. Menuju Kemahiran Berbahasa Indonesia. Surakarta : UNS Press.

Nurgiyantoro, Burhan. 2002. Teori Pengkajian Fiksi. Yogyakarta: Gaja Mada University Press.

Pusat Pembinaan dan Pengembangan Bahasa. 2007. Pedoman Umum Ejaan Bahasa Indonesia yang Disempurnakan. Tera, Yogyakarta.

Ratna, Nyoman Kutha. 2009. Stilistika kajian Puitika Bahasa, Sastra, dan Budaya. Yogyakarta : Pustaka Pelajar

Saefu, Zaman. 2011. Macam-Macam Gaya Bahasa Indonesia. Tersedia di http://situsbahasa.com//. Diunduh pada tanggal 1 Maret 2012.

Sudaryat, Ndang. 1986. Ringkasan Bahasa Indonesia. Bandung: Ganeca Exact

Posted by danriris in Artikel, Tata Bahasa. Tagged: Gaya Bahasa, Jenis Gaya Bahasa. 